\title{
Ethnologies
}

\section{Scottish Traveller Tales: Lives Shaped through Stories. By Donald Braid. (Jackson: University Press of Mississippi, 2002. Pp. xiiii+313, note on transcriptions, ISBN 1-57806-450-3)}

\section{Martin Lovelace}

Volume 26, numéro 1, 2004

Littératie

Literacy

URI : https://id.erudit.org/iderudit/013353ar

DOI : https://doi.org/10.7202/013353ar

Aller au sommaire du numéro

\section{Éditeur(s)}

Association Canadienne d'Ethnologie et de Folklore

ISSN

1481-5974 (imprimé)

1708-0401 (numérique)

Découvrir la revue

Citer ce compte rendu

Lovelace, M. (2004). Compte rendu de [Scottish Traveller Tales: Lives Shaped through Stories. By Donald Braid. (Jackson: University Press of Mississippi, 2002. Pp. xiii+313, note on transcriptions, ISBN 1-57806-450-3)]. Ethnologies, 26(1), 251-253. https://doi.org/10.7202/013353ar d'utilisation que vous pouvez consulter en ligne.

https://apropos.erudit.org/fr/usagers/politique-dutilisation/ 
Scottish Traveller Tales: Lives Shaped through Stories. By Donald Braid. (Jackson: University Press of Mississippi, 2002. Pp. xiii+313, note on transcriptions, ISBN 1-57806-450-3)

This is an enthusiastic and perceptive account of the meaning of storytelling among contemporary Scottish Travellers, a people who "live, eat, and breathe stories." Donald Braid, a convert to ethnology from the world of physics and technology, via the American storytelling revival, and a Ph.D. in Folklore at Indiana, spent a year in Scotland living with Traveller families and recording their traditional stories in 1992-93 for his dissertation research. He made several other visits beginning in 1985 when he first met that avatar of Scottish tale-telling Duncan Williamson, who figures extensively as narrator and commentator on Traveller life in this book. Braid's thesis is that Traveller lives are "shaped through stories," in that storytelling holds a vital place in this itinerant culture, with its needs for memory: for good camping sites, for sources of broom, willow, and other craft-making materials, or for cautionary tales about hostile landowners, and how certain Traveller heroes had outwitted them. The Traveller worldview, making up a differential identity from that of "settled," non-Travellers, is cumulatively assembled through narrating, and reflecting upon, stories: from wonder tales, tall tales and legends, to memorates and ballads. Braid offers admirably close readings of these narratives, informed by the commentaries of their performers and audiences. While storytelling is fundamental to the construction of worldview and identity in every culture, past or present, subaltern or elite, Braid provides a strong argument for its exceptional liveliness and thought-provoking substance within the Traveller families who welcomed him into their homes.

That they should have settled homes at all, as opposed to tents and vans, marks a social change which brings their identity into particular question. Most of Braid's photographs show Travellers performing or listening to stories and songs within the houses which they use in winter, if not year-round, before taking to the road for the summer. There are many authoritarian pressures on Travellers to become settled, but doing so risks assimilation into mainstream Scottish society, and loss of culture and identity. Many Travellers have tried both ways of living, including Duncan Williamson, who has toured the United-States on the storytelling revival circuit, so that the critical evaluation of past and present ways of life is very much part of what is going on as these tales are told about the "old Travellers" among contemporary Traveller, and non-Traveller, audiences. 
Most interesting to my mind is to see how certain international tale types appear when told from Traveller viewpoints. "Cinderella," for example, has no cruel stepmother or jealous sisters in the Traveller version, though Williamson is aware that in the "other life" or the "country folk's way" (174) of telling the tale these characters are significant. The Traveller Cinderella-figure, like real Traveller children, enjoys warm relations with her family, and when she goes to the young laird's party it is out of curiosity to see another way of life, and not as a rejection of her poverty and Traveller upbringing. It is not, as Braid says, a rags to riches story, for the laird's life is not necessarily superior. Living happily ever after includes the bride's family being free to camp on the laird's land as and when they wish; it does not mean that they give up an already satisfying existence to be wealthy according to "settled" standards. What is present in Duncan Williamson's version, however, is a "pattern of discrimination" by the laird's men against Travellers, which is very realistic and "provides one of the driving tensions of the story" (198). As in some other tale collections from Traveller cultures, such as F.H. Groome's In Gipsy Tents (1880), or John Sampson's Gypsy Folk Tales (1933), the Traveller tale world is completely interpenetrated by the real world inhabited by Traveller narrators and audiences. This should not be surprising, but somehow it is. I suspect it is because the settings and themes of these tales are so familiar to us "settled" readers, that they seem suddenly strange when imbued with the separate identity and powerful social critique of a Traveller storyteller.

The question of what is "Traveller" about these tales, then, is satisfyingly explored, both emically by the narrators and etically by Donald Braid. In one case, however, Braid misses an opportunity to note the international elements in Duncan Williamson's tale "The Tinker and the Skeletons." To Williamson this is one of the "real Traveller tales," and Braid muses about it as "a creative presentation of Traveller life" - which it is - and in some way also "a true story," (31) but which he might have identified as a version of Aarne-Thompson 326A* Soul Released from Torment - Herbert Halpert surveys this tale type, which has often been recorded in legend style, in Folktales of Newfoundland (210-214). The Types of the Folktale remains one of the sharpest tools we have for delineating where a common European tradition leaves off and a distinct and creative individual culture begins.

The tales are transcribed in an ethnopoetic manner, which is easy to read yet sensitive to the nuances of performance, and the all- 
important introductory and concluding remarks of the tellers are included. The language of analysis is blessedly clear and Braid's close reading of narrative texts, and contexts, is exemplary. This would make an excellent text for undergraduate or graduate courses in folk narrative since it does so many things so well: ethical fieldwork continued for a substantial period, careful transcription of narrative texts, close observation of performance occasions, good rapport with informants, and all built upon wide knowledge of the literature on Scottish Travellers. The book also deserves an audience beyond academe where general readers may discover the quality of an oral literature, and gain due respect for a people who endured centuries of suspicion and fear. Their lives were not only shaped by stories, they were defended by them.

Martin Lovelace Memorial University St. John's, Newfoundland

\section{References}

Aarne, Antti. 1973. The Types of the Folktale. $2^{\text {nd }}$ rev. Helsinki: Academia Scientiarum Fennica.

Groome, Francis Hindes. 1880 [1973]. In Gipsy Tents. East Ardsley, Yorkshire: EP Publishing.

Halpert, Herbert and J.D.A. Widdowson. 1996. Folktales of Newfoundland: The Resilience of the Oral Tradition. New York: Garland Publishing.

Sampson, John. 1933 [1984]. Gypsy Folk Tales. London: Robinson Publishing.

Little Jack and other Newfoundland Folktales. Par John D. A. Widdowson, dir. (St. John's : Memorial University of Newfoundland, Folklore and Language Publications, 2002. Pp. xiii + 245, ISBN 0-88901363-2).

C'est à partir du milieu des années 1960, au moment où est créé le département de folklore de l'Université Memorial, que la collecte systématique des contes de Terre-Neuve et du Labrador a commencé à l'initiative d'Herbert Halpert. Cette collecte, effectuée le plus souvent dans des villages côtiers isolés (dont plusieurs n'avaient pas encore l'électricité), a permis de mettre à jour un répertoire qui, à l'époque, n'était déjà plus vivant dans la plupart des autres cultures anglo- 